\title{
The Rise of Populism Wave in Visegrad Group Countries and How It Prevails: A Socio-Economic Perspective
}

\section{Rufaida Nurul Vicri}

Undergraduate Student of International Relations Department at Universitas Katolik Parahyangan rufaidanurulvicri10@gmail.com

\begin{abstract}
Penulisan makalah penelitian ini bertujuan untuk menilik dan mengkaji adanya tendensi politik negara-negara Visegrad yang telah jatuh pada gelombang populisme. Grup Visegrad (V4) merupakan grup aliansi antara empat negara di kawasan Eropa Timur dan Tengah (ETT), yakni: Republik Ceko, Slowakia, Hongaria, dan Polandia. Penelitian ini akan menggunakan pendekatan-pendekatan sosial-ekonomi untuk mengkaji latar belakang munculnya gerakan populisme di kawasan tersebut. Makalah ini akan berusaha untuk menjawab tentang bagaimana latar belakang kemunculan gerakan politik populisme dalam negara-negara Visegrad? Untuk menjawab pertanyaan penelitian di atas, analisis ini dilakukan dengan menggunakan pendekatan Materialisme Historis dan Determinisme Ekonomi Marx serta Tesis Ekonomi Downsian.
\end{abstract}

Keywords: populism, Visegrad Group, socio-economic, historical materialism, economic deteminism

\section{Introduction}

The phenomenon of rising populism in regions such as East-Central Europe has become one of the most alarming international political issues of this era. Liberalism is increasingly challenged by the adoption of populist-oriented rhetoric and political actions as seen from the case in all four Visegrad countries. With the existence of complex social, economic, and geopolitical issues such as the continuous influx of both legal and illegal immigrants from conflict-prone neighboring countries, it is easy for populism to thrive and survive. To be more specific, this paper uses Visegrad group countries case to serve as an example of how populism has become 'the trend' in East-Central Europe region and why. 
Visegrad group countries is an alliance group between four East-Central European states which include the Czech Republic, Hungary, Poland, and Slovakia which are also full members in both European Union as well as NATO; all joined in $2004 .{ }^{1}$ Despite being relatively new to the status of membership in the organizations, these new members have shown significant contributions as some very vocal members of the EU. Regardless, having to meet diverging issues on topics such as structural issues in the EU and immigration, the "euroskepticism" amongst the politicians and people alike has been on the move. ${ }^{2}$ But there is a more underlining factor behind the euroskepticism movements within the region: the wave of populism. Therefore, this paper aims to answer this fundamental question of populism in the Visegrad group countries: how did waves of populism in Visegrad countries become a major trend in the region and within each country?

There are a wide variety of aspects and dimensions on how to perceive populism in Visegrad countries, and the socio-historical aspect of the issue has been widely cited as the most important. The socio-historical rationale has been built on the very nature of each Visegrad country history as ex-communist states, the remnants of the Cold War who turned to their Western counterparts, mainly in search for "American dream" of the people who want better opportunities and security after surviving years of torments caused by dictatorship and fascism. ${ }^{3}$ Nevertheless, this paper concentrates not so much on the ideological factor of Visegrad countries history but focusing instead on the socio-economic background behind Visegrad countries' fall to populism after many years of struggle to dismantle 'the iron grip' for liberalism and democracy.

The four Visegrad countries slowly turned their backs on liberal democracy they were yearning to have. On another note, we can see how the Czech Republic has obtained the "most euroskeptic country" status out of her three counterparts. ${ }^{4}$ The Czech Republic currently holds

\footnotetext{
1 "The Bratislava Declaration of the Prime Ministers of the Czech Republic, the Republic of Hungary, the Republic of Poland and the Slovak Republic on the occasion of the 20th anniversary of the Visegrad Group," International Visegrad Fund, 15 February 2011, accessed 20 October 2018, http://www.visegradgroup.eu/2011/the-bratislava.

${ }^{2}$ Krisztina Vida, EU Governance Trends - Dillemas and Recomandations for Visegrad Countries, $\|$ in Prospects of the Visegrad Cooperation, Identifying Converging and Diverging Factors, ed. Gábor Túry (Budapest: Institute of World Economics, 2015), 9-31.

${ }^{3}$ Martin Bútora, "Nightmares from the Past, Dreams of the Future," Journal of Democracy 18, no. 4 (10, 2007): 48, accessed 20 October 2018, https://search.proquest.com/docview/195550473? accountid=31495.

${ }^{4}$ Mihai Huszarik, "Important Changes in Central Europe. the Evolution of Visegrad Countries," Eurolimes 20, (Autumn, 2015): $237, \quad$ accessed $20 \quad$ October https://search.proquest.com/docview/1794151799?accountid=31495.237.
} 
the second lowest attendance at the elections for the European Parliament. The euroscepticism in the country was especially apparent during the economic crisis, when the economy of the Czech Republic suffered big losses. ${ }^{5}$ Furthermore, albeit all four Visegrad countries have shown good performance on their overall economy, ${ }^{6}$ this economic growth doesn't suffice in justifying the similar positive increase on the topics such as welfare and standard of living. The decline in consumption and unequal distribution of wealth are some of the most prevalent issues. ${ }^{7}$ The author believes that these growing economic issues, albeit not at its worst, had become major concerns by the people of each Visegrad country while the political elites exploited their fears and furies to gain mass support, and subsequently: political power. It is also important to note that the swell of populism waves surge upwards around the year 2008 to 2011, coincided with the all-time high fiscal crisis of the $21^{\text {st }}$ century. ${ }^{8}$

Determining the complex background of proliferation on populism in a region is a difficult attempt. Therefore, this paper seeks to simplify the analysis by focusing on the socioeconomic aspects of populism in Visegrad countries. To do that, this paper uses concepts and theories to frame the analysis. The author believes that Marxian Historical Materialism and Economic Determinism can serve as an 'umbrella' to see why economic aspects behind the historical analysis are important. The author also uses Economic Thesis of Populism, initially developed from rational-choice theory introduced by Anthony Downs in 1957. This paper will be separated in a sequence starting from the theoretical framework used for analysis. Next, the paper will be divided into two body chapters that include explanations on current populism trends and issues facing all four Visegrad countries. The second one will be dealing with an analysis on the socio-economic dimension of populism in Visegrad countries, conceptualized by theoretical frameworks mentioned earlier.

\section{Theoretical Framework: A Socioeconomic Approach}

\section{a. Marxian Historical Materialism and Economic Determinism}

\footnotetext{
${ }^{5}$ Ibid.

${ }^{6}$ Krisztina Vida, Past, Present and Future Macroeconomic Trends of the Visegrad Countries: Heading towards more Convergence?, $\|$ in Prospects of the Visegrad Cooperation, Identifying Converging and Diverging Factors, ed. Gábor Túry (Budapest: Institute of World Economics, 2015), 123.

${ }^{7}$ Simon Tilford, "All is not well in the Visegrad economies," Centre for European Reform Issue 117, 29 November 2017, accessed 20 October 2018, https://www.cer.eu/publications/archive/bulletin-article/2017/all-not-wellvisegrad-economies.

${ }^{8}$ David Molloy, "What is populism, and what does the term actually mean?," BBC News, 6 March 2018, accessed 20 October 2018, https://www.bbc.com/news/world-43301423.
} 
Marxian Economy theory in this paper will serve as an 'umbrella' to conduct socioeconomic analysis on populism. Marxism is a philosophy of social existence, called historical materialism which was founded by Karl Marx (1818-1883) and Friedrich Engels (1820-1895). Largely differ from its main counterpart, the Hegelian Idealism, historical materialism doesn't corroborate an explanation that emphasizes ideas as a leading cause of events in history. On the contrary, Marx and Engels developed the conception of "historical materialism" to answer questions regarding social existence. Thus, Marx and Engels believed that consciousness was the product of matter rather than its origin. In a socio-economic perspective with correlation to political spectrum and ideas, Marxist historical materialism posits that social classes and the relationship between them, along with the political structures and ways of thinking in society, can be inferred to be founded on and reflect contemporary economic activity. ${ }^{9}$

Next, another popular concept from Marxism Economic in a historiographic study of social existence is an economic determinism. Marx's conception of economic determinism has a number of implications for what is generally understood as "freedom of the will" suggested by the environment. For Marx, that environment itself arises from general economic conditions. ${ }^{10}$ Furthermore, the theory stresses that societies are divided into competing economic classes whose relative political power is determined by the nature of the economic system. Through concepts of historical materialism and economic determinism, we can infer that the birth of populism within a nation resulted on material aspects of human history such as economic when there still exists the proletary and the bourgeoise.

Economic Thesis of Populism

The economic thesis wasn't originally concerned itself with populism, rather, this thesis came first as a Downsian rational-choice theory to the study of democratic politics (1957). Nevertheless, the general idea of the theory provides the basis for future studies regarding populism. The basic idea is similar: voters and politicians are essentially materially selfinterested. ${ }^{11}$ Arguments tend to fall into three categories, which interpret populism as follow:

\footnotetext{
${ }^{9}$ Richard Peet and Elaine Hartwick, Theories of Development Contentions, Arguments, Alternatives, Second edition (New York: The Guilford Press, 2009), 143-148.

${ }^{10}$ Estelio Iglesias, "Dialectical Materialism and Economic Determinism: Freedom of the Will and the Interpretation of Behavior," Athene Noctua: Undergraduate Philosophy Journal Issue No. 2 (Spring 2014), 2.

${ }^{11}$ Kirk Hawkins, Madeleine Read, and Teun Pauwels, "Populism and Its Causes," The Oxford Handbook of Populism Edited by Cristóbal Rovira Kaltwasser, Paul Taggart, Paulina Ochoa Espejo, and Pierre Ostiguy, Nov 2017, 5-6, DOI: 10.1093/oxfordhb/9780198803560.013.13.
} 
(1) Medium-term Structural Change ("the globalization losers" thesis): this thesis main ground lies in these "losers" of globalization; the unemployed, the underemployed, the unskilled, and those whose jobs are threatened by advancing technology. These people generally feel under-represented by traditional mainstream parties, so they turn instead to populist parties of the left and right. ${ }^{12}$ The bottom line is, populist parties are a response to the electoral space created by a changing electorate and an unresponsive party system. ${ }^{13}$

(2) Failures of Democratic Governance: this thesis explains that populism is a response to long-term problems of weak democratic governance, especially political corruption. Where corruption thrives, citizens feel unfairly treated by authorities and are persistently dissatisfied with the functioning of democracy. ${ }^{14}$ Furthermore, corruption is one of the most crucial conditions in the pathways towards the success of anti-establishment parties in Central Europe, a concept that comes close to populism. ${ }^{15}$ Populist parties, frequently led by candidates who cast themselves as political outsiders, become the natural recourse for the disadvantaged. ${ }^{16}$

(3) Institutions and the Electoral Space: in this thesis, populism concerns with politicians' strategies to address the demands of the under-represented people (the political "supply") through electoral opportunity structure; the interactions among mainstream parties within the electoral arena. ${ }^{17} \mathrm{~A}$ high level of electoral volatility combined with a large space in the electoral arena (i.e. mainstream parties ignoring issues which voters find important) is generally beneficial for populist parties. Immigration is such an issue on which mainstream parties originally did not position themselves too strongly, explaining why national populists could exploit this niche. ${ }^{18}$

Besides the electoral system, the electoral opportunity structure of populist parties can be determined by analyzing the organizational capacities of party leaders. This means that

\footnotetext{
${ }^{12}$ Hans-Georg Betz, Radical Right-Wing Populism in Western Europe (New York: St. Martins Press:1994).

${ }^{13}$ Kirk Hawkins, Madeleine Read, and Teun Pauwels, "Populism and Its Causes," The Oxford Handbook of Populism Edited by Cristóbal Rovira Kaltwasser, Paul Taggart, Paulina Ochoa Espejo, and Pierre Ostiguy, Nov 2017, 7, DOI: 10.1093/oxfordhb/9780198803560.013.13.

${ }^{14}$ Hanspeter Kriesi, “The populist challenge,” West European Politics, 37(2), 2014: 361-78.

${ }^{15}$ Seán Hanley and Sikk Allan, "Economy, corruption or floating voters? Explaining the breakthroughs of antiestablishment reform parties in eastern Europe," Party Politics, 22(4), 2014: 522-33.

${ }^{16}$ Kirk Hawkins, Madeleine Read, and Teun Pauwels, "Populism and Its Causes," The Oxford Handbook of Populism Edited by Cristóbal Rovira Kaltwasser, Paul Taggart, Paulina Ochoa Espejo, and Pierre Ostiguy, Nov 2017, 7, DOI: 10.1093/oxfordhb/9780198803560.013.13.

${ }^{17}$ Ibid, 8.

${ }^{18}$ Huib Pellikaan, Tom Van der Meer, and Sarah De Lange, "The road from a depoliticized to a centrifugal democracy," Acta Politica, 38(1), 2003: 23-49.
} 
charismatic leaders who are commonly found in populist parties whose persona are more appealing to the eyes of the general public in the grassroots level instead of the rustic leadership of traditional parties which refuses to adapt. As will be presented later in the following sections, populism in the Visegrad countries exhibit trends of populism which fall into all categories explained earlier which affect each other simultaneously.

\section{Rising Populism in Visegrad Group Countries: Current Trends and Issues}

Visegrad group states is a regional grouping established in February 1991 in Visegrad, Hungary, which was intended to be a political alliance, originally conceived to coordinating the post-communist transformation to join the European Union. ${ }^{19}$ However, despite having achieved a generally positive growth on their overall economy as well as successful democratic consolidation marked by obtaining membership in the EU, these Visegrad group states have all succumbed to populism. The rise eventually spread further in around mid-2010s when Hungary and Poland abruptly shifted towards illiberalism.

Populism surged ahead in the year of elections in East-Central Europe around 2015. In Poland, after the 2015 election, the victorious right-wing Law and Justice Party-which was mostly popular for the working-class voters in eastern Poland-finally 'showed its claw' when the party curbed freedom and democracy; resulted in waves of public protests taken on the streets. ${ }^{20}$ In the Czech Republic, the conventional trend of populism was established with the reelection of President Milos Zeman; the infamous president who often sold populism branded rhetoric through disseminating hate-speech towards Muslim immigrants. He is also an ally of the Prime Minister Andrej Babis, a billionaire and leader of a right-wing party. ${ }^{21}$ Perhaps in Hungary, the situation is also similar, if not much bleaker. The country is now run by right-wing Fidesz party with Viktor Orban, a right-wing nationalist, currently holds the seat as prime minister. ${ }^{22}$ Hungary is often accused by many as to propel similar movements on fellow EU members such as Poland and Italy. Since 2010, the party has orchestrated numerous populistic

\footnotetext{
${ }^{19}$ Jan Pakulski, The Visegrad Countries in Crisis (Warsaw: Collegium Civitas, 2016), 7.

${ }^{20}$ Wojciech Moskwa and Rodney Jefferson, "Poland's Populist Turn," Bloomberg, 26 December 2017, accessed 4 November 2018, https://www.bloomberg.com/quicktake/poland.

${ }^{21}$ Marc Santora, "Czech Republic Re-elects Milos Zeman, Populist Leader and Foe of Migrants," The New York Times, 27 January 2018, accessed 4 November 2018, https://www.nytimes.com/2018/01/27/world/europe/czechelection-milos-zeman.html.

${ }^{22}$ Steven Erlanger, "In Eastern Europe, Populism Lives, Widening a Split in the E.U.," The New York Times, 28 November 2017, accessed 4 November 2018, https://www.nytimes.com/2017/11/28/world/europe/populism-easterneurope.html.
} 
propaganda such as euroskepticism, xenophobic ideals, and anti-immigration speech and law. ${ }^{23}$ It is no better in Slovakia as well although the pattern is slightly different. In this case, Slovakian recently resigned (rather forcefully) Prime Minister Robert Fico is a left-wing populist. He was later replaced by his long-standing ally; Peter Pellegrini. Nevertheless, to analyze the populism trends and issues in each Visegrad country, one must have prior understanding on the definition of "populism" itself.

This paper will rely on a populism definition delivered by Mudde and Kaltwasser. They described populism as "a thin-centered ideology that society is separated into 'the pure people' and 'the corrupt elite'." 24 This means that populism embraces many forms and can be attached to other "thick-centered" ideologies such as fascism-nationalism as seen from the right-wing populism or to concentrate on socialism for the left-wing populism case. ${ }^{25}$ Yet, the notion of populism that can be taken to mean as an ideology that addresses the interests and ideas of "common people", while the elites use it as a tool to beat political rivals, is arguably the most popular argument to comprehend the complex and abstract term. In the Visegrad countries case, the author believes that the populism trend seems to be showing both right and left-wing populism category or a combination of both. For example, there is Viktor Orban, current prime minister of Hungary who also happens to be a prominent right-wing political figure associated with nationalistic ideals and an avid supporter of anti-immigrant law. On the other hand, there is an ex-prime minister of Slovakia, Smer Robert Fico, a leader of a left-wing Slovak SocialDemocratic Party who used socialist-theme, "for the people" rhetoric such as free health-care system and other social welfare programs to beat his fellow liberal political opponent, Mikulas Dzurinda, for the 2006 election. ${ }^{26}$

As explained earlier, each Visegrad country is rife with populist politics. Even if the grand picture seems to be similar, each case from each state is unique and present us with different features and aspects. The background and characteristic of each state are not the same either. But there is also a common ground, which, the author argues, largely attributed to a historical materialism aspect; in this respect, the social and economic condition of each state.

\footnotetext{
${ }^{23}$ Ferenc Laczó, "Populism in power in Hungary: Consolidation and ongoing radicalization," Eurozine, 27 March 2018, accessed 4 November 2018, https://www.eurozine.com/populism-power-hungary/.

${ }^{24}$ Cas Mudde and Cristóbal Rovira Kaltwasser, Populism: A Very Short Introduction (New York: Oxford University Press, 2017), 6.

25 Ibid.

${ }^{26}$ Peter Sprinz, "Populism and Nationalism in the V4: Temporary Setback," International Visegrad Fund, accessed 20 October 2018, http://www.visegradgroup.eu/students-section/populism-and.
} 


\section{The Socio-economic Dimension of Populism in the Visegrad Group Countries: Economic} Thesis of Populism Analysis

One way to analyze populism politics is by attempting to discern factors which contribute and catalyze the rise of populism wave in a specific country or region. Endeavors to achieve such result in a qualitative study is not to ignore the historical background behind a certain phenomenon. One can look at history from the ideological or a cultural aspect, but those aren't the only ways to understand the background history behind social and political conditions of a nation. In this respect, this paper attempts to draw an analysis from a socio-economic perspective. In a broad-sense, socio-economic means "social and economic" which refers to "the use of economics in the study of society". ${ }^{27}$ Since economic aspects would be the focus in this paper, a historical leaning of the analysis will use Marxian historical materialism described earlier. The reason for it being that social existence is defined by material objects such as production process or simply economic aspects; not ideas or other intangible factors such as human consciousness.

As for the rationale of why the author chose to conduct analysis based on socio-economic grounds, the economic thesis of populism is one method which could provide an explanation of why economy is a significant factor behind the birth of populism. The issues and current developments of populism in each Visegrad country had been previously conveyed. But there is still an underlying question of what kind of socio-economic factors drove the upsurge of populistic ideals in the region.

In reality, economic growth in all Visegrad countries actually showed satisfying results. Almost all V4 countries have an exceptionally low unemployment rate. Whereas the average in the EU was estimated by Eurostat to be at $7.3 \%$ in January 2018, the Czech Republic led the numbers $(2.4 \%)$, Hungary $(3.8 \%)$, Poland (4.5\%), and last, Slovakia with the least good result (7.5\%). Still, the number can't be compared in condition such as that of Greece $(20.9 \%) .{ }^{28}$ As in 2016, GDP per capita in the Visegrad four ranged from $64 \%$ of eurozone levels in Poland to $82 \%$

\footnotetext{
${ }^{27}$ John Eatwell, Murray Milgate, and Peter Newman, Social Economics (London: Palgrave Macmillan, 1989), 12.

${ }^{28}$ Michał Kowalczyk "The countries of the Visegrad Group opened 2018 with good indicators," Central European Financial Observer, 19 April 2018, accessed 4 November 2018, https://financialobserver.eu/poland/the-countriesof-the-visegrad-group-opened-2018-with-good-indicators/.
} 
in the Czech Republic. The Czech Republic, Slovakia and Poland have experienced significant convergence in GDP per capita with the eurozone over the last ten years. ${ }^{29}$

Yet the numbers alone can't explain dissatisfactions found amongst the people living in those countries. Today, the entire region is facing security threats, economic stagnation, immigration crises, and a strong populist anti-liberal backlash. ${ }^{30}$ The 2008 crisis, which morphed into the pan-European economic slowdown, has weakened the liberal consensus within the EU and V4. The Polish political elites had initially succeeded in maneuvering through the 2008-9 crisis, at least partly due to Poland's collaboration with Germany, conservative financial policies and generous EU subsidies. The Hungarian, Slovak, and Czech political elites experienced deep recessions, and they adopted more "national" and "interventionist" strategies of recovery, currently embraced also by Poland. ${ }^{31}$ Refugees, now mixed with economic migrants, have been triggered a powerful anti-liberal and anti-immigration backlash coming from the populistsnationalists, who portray immigrants as job-takers. ${ }^{32}$ Later, euroskepticism was rising due to the EU unpreparedness for such crisis. Although the main crisis which propelled the rise of populistnationalist in the region was largely thanks to the "refugees tsunami", the main reason why the crisis is feared by the people is largely about security and economy.

While refugee factor is viewed by many as a hindrance for their economic well-beings, economic issues facing Visegrad countries are more than that. Growth in consumption has lagged behind the GDP growth and there is also disproportionate capital distribution. In the case of Visegrad countries, the rewards of the economy tend to go for the owners of capital, and they are mostly foreigners. ${ }^{33}$ This exacerbates further the people's skepticism towards the spirit of liberalism. This is when the first and the second category of populism economic thesis come into play: first, the medium-term structural change. People who feel marginalized, the so-called "losers of globalization" who can't keep up with rising competitions and changes, long for the emergence of political figures who would listen and bring actions for these kinds of novel problems rather than relying on mainstream parties they no longer believe in.

\footnotetext{
${ }^{29}$ Simon Tilford, "All is not well in the Visegrad economies," Centre for European Reform Issue 117, 29 November 2017, accessed 20 October 2018, https://www.cer.eu/publications/archive/bulletin-article/2017/all-not-wellvisegrad-economies.

${ }^{30}$ Jan Pakulski, The Visegrad Countries in Crisis (Warsaw: Collegium Civitas, 2016), 8.

${ }^{31}$ Ibid, 9.

32 Ibid.

${ }^{33}$ Simon Tilford, "All is not well in the Visegrad economies," Centre for European Reform Issue 117, 29 November 2017, accessed 20 October 2018, https://www.cer.eu/publications/archive/bulletin-article/2017/all-not-wellvisegrad-economies.
} 
Next, low performance on democratic governance as seen by divisive class in each state where the foreigners (capital owners) benefit more than the locals causes the people to yearn for reforms. In order to achieve more equal economy, these states should try to solve the biggest issue for their economy: demographic. Currently, the region is commonly faced with low birth rates and aging population. This, in turn, affects lower performance on education sectors as the high-skilled workers went to their more prosperous Western counterparts. ${ }^{34}$ Instead of trying to eradicate the root causes of these economic issues and strengthen cooperation in domestic level or turn into more regional economic partnerships between Visegrad states with more openness, the governments and the people turned instead to populism.

The globalization losers and failures of democratic governance thesis affect one another in a way which resulted in the third category of the thesis: the institutions and the electoral space. In Czech Republic, populist leader and "a fan" of Russia, Milos Zeman, was reelected the second time as president in January 2018. Despite Russian meddling allegations, his win was mostly influenced by deep divisions in Czech society and his ability to exploit the fears of marginalized Czechs who live outside prosperity. He portrayed himself as the "savior for the common people" while most of his campaigns were conducted in small towns and villages. Zeman's bluntness, whenever he got the chance to deliver his political—or not-so-political—opinions to the public is considered one of his best qualities for his supporters. He also took advantage of the migrant crisis, a rather unexpected and sudden crisis no previous governments were prepared for. He sought to seal off the country and defied efforts by the European Union to force member nations to share the burden equally by taking in migrants through a quota system. ${ }^{35}$ We can infer that Zeman is the "charismatic leader" who is liked by common people despite his controversial antics.

In Poland, the situation is not much different and socio-economic aspects were also the main drive behind populism politics in the country. Populism in this country is also packed with nationalist movements and socialism campaigns style. Even when the economy was going in positive directions, inequality of wealth and elite failures described as "self-serving" became the main forces behind the Poles supports for the populist party in the 2015 election. But of course,

\footnotetext{
${ }^{34}$ Ibid.

${ }^{35}$ Marc Santora, "Czech Republic Re-elects Milos Zeman, Populist Leader and Foe of Migrants," The New York Times, 27 January 2018, accessed 4 November 2018, https://www.nytimes.com/2018/01/27/world/europe/czechelection-milos-zeman.html.
} 
just like any right-wing populist anywhere, the Poles are now forced to face controlling leadership and government's attempts to curb democracy, freedom, and tolerance. The ruling party refuses to let refugees in, oppose gay marriage, restriction to get an abortion, hinder demonstrations, and to weaken the constitutional court. Meanwhile, the pattern behind the Law \& Justice party win, led by far-right conservative Jaroslaw Kaczynski, remains the same: the party promised to reduce the tax burden on the poor and increase payments to families with children. It struck a nerve by calling for the country to assert its national identity and control its borders. $^{36}$

Shifting to Hungary, the name Viktor Orban, the current man in power of the country, would ring as the radical far-right nationalist, the one who propelled the populism wave in the region. In Hungary, the situation is perhaps even more dire as Orban, as well as his counterpart Kaczynski from Poland, both have an ambition to rule the Visegrad group four. ${ }^{37}$ This exacerbates further into a regional level as relations between Hungary and Poland has become fragile as the men often differ in opinions. Moreover, Slovak's dislike towards Orban and Czech Republic's distrust towards Kaczynski further worsen the fragmentation between neighboring states. ${ }^{38}$ Populism issues within the states will spoil further in the regional level amongst Visegrad states and would threaten to cause conflicts and instabilities in the region.

In the domestic level, the situation is worse. The rise of populism through socioeconomic perspective in Hungary can be traced far back since the Cold War era. But the most defining factor of this era can be seen since 2010. With Fidesz party came in power in the 2010, majoritarianism, centralization, weakened constitutional guarantees, curtailed civic and property rights, as well as muzzled media have become central features of the new regime. It is also extending its control over economy and society through systematic clientelism, confrontation with the oligarchs, as well as control of civic organizations and the media. The prevailing political rhetoric is nationalistic and populist with the emphasis on a "Europe of nations". 39 Proven to be a game-changer in populism power play was the existence of Viktor Orban, a charismatic far-right leader with a strong persona in declining government institutions due to

\footnotetext{
${ }^{36}$ Wojciech Moskwa and Rodney Jefferson, "Poland's Populist Turn," Bloomberg, 26 December 2017, accessed 4 November 2018, https://www.bloomberg.com/quicktake/poland.

${ }^{37}$ Jan Pakulski, The Visegrad Countries in Crisis (Warsaw: Collegium Civitas, 2016), 11-12.

${ }^{38}$ Ibid, 10.

${ }^{39}$ Ibid, 42.
} 
2008 financial crisis and economic stagnation. ${ }^{40}$ The political demonstrations and riots due to increased Hungarian's disillusions towards institutional inefficiency gave an easy win for Fidesz and the wane of liberal democracy.

Lastly, in Slovakia case, the turning-point started at the advent of refugee crisis in Europe. Since then, Robert Fico's party, Smer-SD, gained considerable mass supports and eventually won the election. The background was the same just like her three counterparts: Fico used propaganda to gain public's sympathy and was using campaign slogan such as "We Protect Slovakia". The ex-PM began to make international headlines with hate-speech such as "we do not have mosques in Slovakia, so they cannot integrate" or "there will be no Muslim community in Slovakia". ${ }^{41}$ What is unique in the Slovakia's case was that the Smer-SD party completely abandoned the refugee crisis issues as they want to be seen as "loyal partner" of the EU; in contrast with the other Visegrad countries. This doesn't mean that populism in the country has receded, in fact, it got worse with the emergence of the People's Party, Our Slovakia (LS-NS) of Marian Kotleba. The radical far-right started to enter the parliament as it had gained $8 \%$ of the popular vote for the first time ever since the Smer-SD took power. Kotleba's supporters are most concerned with social inequality and corruption, and not refugees. The People's party appeals to the voters by presenting an anti-establishment profile, which promises to cope with all "problems": social injustice, corruption, and "disorderly" Roma people. ${ }^{42}$ Therefore, once again, socio-economic factors are very significant behind the rise of populism in the Visegrad countries.

The economic thesis found in the Visegrad countries case is very obvious. As explained earlier, populist parties and politicians tend to be more flexible with their ideological positions and able to promote popular candidates. Rising new issues such as migrant crisis which has never been a focus for the previous governments become a great tool for power grab in the domestic political field. Populist parties are more likely to persist when charismatic leaders are able to recruit competent party personnel, organize campaigns professionally, and keep the party united. Such parties gradually become perceived as competent, united, and trustworthy, making them credible alternatives to established parties over time. ${ }^{43}$ The bottom line is, populism

\footnotetext{
${ }^{40}$ Ibid, 33.

${ }^{41}$ Ibid, 69.

${ }^{42}$ Ibid, 70.

${ }^{43}$ Kirk Hawkins, Madeleine Read, and Teun Pauwels, "Populism and Its Causes," The Oxford Handbook of Populism Edited by Cristóbal Rovira Kaltwasser, Paul Taggart, Paulina Ochoa Espejo, and Pierre Ostiguy, Nov 2017, 8, DOI: 10.1093/oxfordhb/9780198803560.013.13.
} 
anywhere shows a strikingly similar pattern: a fusion between socialism and nationalism which shade a phenomenon of populist parties and leaders' exploitation on an amalgam of hope, fear, and fury; all the while hiding under the magic word: "people".

\section{Conclusion}

I stand in my belief that the economic factors are significant in building the blocs for populism. Economic issues had become major concerns by the people of each Visegrad country other than security issues while the political elites exploited their fears and furies to gain mass supports in order to ensure their political power within state. The existence of the marginalized segment of people who can't survive the globalization and faced with daily economic problems, mixed with their distrusts towards mainstream political elites and institutions who can't provide better change, ultimately give the room for dislikes towards liberal democracy in general. In turn, the populist parties and elites who share socialist and nationalistic ideals, use strategy to exploit the unstable political situations by appealing to the general public with economic and welfare promises as well as selling the notion of "change".

The Visegrad group four isn't supposed to lose its purpose as a regional alliance after the dissolution of communism. As socio-economic factors are definitely one of the main factors behind the rapid rise of populism in the region, the alliance should try to increase the spirit of regionalism and cooperation, especially to strengthen economic partnerships. They share similar economic issues such as economic stagnation, unequal distribution of wealth, and demographic crisis. Nevertheless, if populism wave within each state resulted in political instabilitycombined with distrusts amongst political leaders of the Visegrad countries - the notion of cooperation remains to be farfetched. 


\section{Bibliography}

$\underline{\text { Books }}$

Betz, Hans-Georg. Radical Right-Wing Populism in Western Europe. New York: St. Martins Press, 1994.

Eatwell, John, Murray Milgate, and Peter Newman. Social Economics. London: Palgrave Macmillan, 1989.

Mudde, Cas and Cristóbal Rovira Kaltwasser. Populism: A Very Short Introduction. New York: Oxford University Press, 2017.

Pakulski, Jan. The Visegrad Countries in Crisis. Warsaw: Collegium Civitas, 2016.

Peet, Richard and Elaine Hartwick. Theories of Development Contentions, Arguments, Alternatives, Second edition. New York: The Guilford Press, 2009.

Vida, Krisztina. EU Governance Trends - Dillemas and Recomandations for Visegrad Countries, in Prospects of the Visegrad Cooperation, Identifying Converging and Diverging Factors, ed. Gábor Túry. Budapest: Institute of World Economic, 2015.

Vida, Krisztina. Past, Present and Future Macroeconomic Trends of the Visegrad Countries: Heading towards more Convergence?in Prospects of the Visegrad Cooperation, Identifying Converging and Diverging Factors, ed. Gábor Túry. Budapest: Institute of World Economics, 2015.

\section{Journal Articles}

Hanley, Seán and Sikk Allan. "Economy, corruption or floating voters? Explaining the breakthroughs of anti-establishment reform parties in eastern Europe." Party Politics, 22(4), 2014.

Iglesias, Estelio. "Dialectical Materialism and Economic Determinism: Freedom of the Will and the Interpretation of Behavior." Athene Noctua: Undergraduate Philosophy Journal Issue No. 2 (Spring 2014).

Kriesi, Hanspeter. “The populist challenge.” West European Politics, 37(2), 2014.

Pellikaan, Huib, Tom Van der Meer, and Sarah De Lange. "The road from a depoliticized to a centrifugal democracy." Acta Politica, 38(1), 2003. 


\section{$\underline{\text { E-Journal Articles }}$}

Bútora, Martin. "Nightmares from the Past, Dreams of the Future." Journal of Democracy 18, no. 4 (10, 2007). https://search.proquest.com/docview/195550473?accountid=31495.

Hawkins, Kirk, Madeleine Read, and Teun Pauwels. "Populism and Its Causes," The Oxford Handbook of Populism. Edited by Cristóbal Rovira Kaltwasser, Paul Taggart, Paulina Ochoa Espejo, and Pierre Ostiguy, Nov 2017, DOI: 10.1093/oxfordhb/9780198803560.013.13.

Huszarik, Mihai. "Important Changes in Central Europe. the Evolution of Visegrad Countries." Eurolimes 20 ,

(Autumn, 2015). https://search.proquest.com/docview/1794151799?accountid=31495.237.

Online News Articles and Websites

"The Bratislava Declaration of the Prime Ministers of the Czech Republic, the Republic of Hungary, the Republic of Poland and the Slovak Republic on the occasion of the 20th anniversary of the Visegrad Group," International Visegrad Fund, 15 February 2011, accessed 20 October 2018, http://www.visegradgroup.eu/2011/the-bratislava.

Erlanger, Steven. "In Eastern Europe, Populism Lives, Widening a Split in the E.U." The New York Times. 28 November 2017. Accessed 4 November 2018. https://www.nytimes.com/2017/11/28/world/europe/populism-eastern-europe.html.

Kowalczyk, Michał. "The countries of the Visegrad Group opened 2018 with good indicators." Central European Financial Observer. 19 April 2018. Accessed 4 November 2018. https://financialobserver.eu/poland/the-countries-of-the-visegrad-group-opened-2018with-good-indicators/.

Laczó, Ferenc. "Populism in power in Hungary: Consolidation and ongoing radicalization." Eurozine. 27 March 2018. Accessed 4 November 2018. https://www.eurozine.com/populism-power-hungary/.

Molloy, David. "What is populism, and what does the term actually mean?." BBC News. 6 March 2018. Accessed 20 October 2018. https://www.bbc.com/news/world-43301423.

Moskwa, Wojciech and Rodney Jefferson. "Poland's Populist Turn." Bloomberg. 26 December 2017. Accessed 4 November 2018. https://www.bloomberg.com/quicktake/poland. 
Santora, Marc. "Czech Republic Re-elects Milos Zeman, Populist Leader and Foe of Migrants." The New York Times. 27 January 2018. Accessed 4 November 2018. https://www.nytimes.com/2018/01/27/world/europe/czech-election-milos-zeman.html.

Sprinz, Peter. "Populism and Nationalism in the V4: Temporary Setback." International Visegrad Fund. Accessed 20 October 2018. http://www.visegradgroup.eu/studentssection/populism-and.

Tilford, Simon. "All is not well in the Visegrad economies." Centre for European Reform Issue 117. 29 November 2017. Accessed 20 October 2018. https://www.cer.eu/publications/archive/bulletin-article/2017/all-not-well-visegradeconomies. 